\title{
Nota sobre a Resenha das Estruturas Elementares do Parentesco por Simone de Beauvoir
}

Mauro W. Barbosa de Almeida (UNICAMP)
Estruturas Elementares do Parentesco foi publicado em 1949, e no mesmo ano foi publicado $O$ Segundo Sexo, de Simone de Beauvoir. A simultaneidade cronológica de obras que tratam das relações entre homens e mulheres, uma sob o prisma da teoria do parentesco e do casamento em sociedades sem escrita, e outra com apoio na filosofia, na crítica literária e nas ciências humanas e naturais, seria suficiente para sugerir uma relação entre elas. Mas não é preciso especular muito a respeito, já que a relação entre as obras é indicada tanto por Simone de Beauvoir, que agradece a Lévi-Strauss, em nota de rodapé, por ter dado a ela acesso às provas das Estruturas Elementares, como pela resenha que dedicou no mesmo ano à obra de Lévi-Strauss.

Qual foi o efeito da leitura das Estruturas Elementares do Parentesco sobre o O Segundo Sexo? Sobre essa questão polêmica, é possível dar duas indicações. A primeira, mais simples e fatual, é que, ao tratar da história das relações entre homens e mulheres, Simone de Beauvoir invoca o tratado de Lévi-Strauss para rejeitar a existência histórica do matriarcado como fase da história humana (conforme a tese de Bachofen retomada por Engels), já que, em todas as sociedades conhecidas, "a autoridade pública ou simplesmente social pertence sempre aos homens". O matriarcado é retido contudo como mito, e embora Simone de Beauvoir continue a ecoar a tese de Bachofen e de Engels com a noção de uma "revolução" efetuada com a substituição da filiação uterina pela agnática (pág. 129, nota 1), ela escapa à confusão freqüente entre filiação uterina e matriarcado.

Contudo, o efeito mais importante da leitura das Estruturas Elementares do Parentesco não foi essa atualização com a etnologia da época via Lévi-Strauss, e sim o apoio fornecido por essa obra à noção de que a chave conceitual para pensar a mulher é situá-la em uma relação de alteridade: a mulher é estrutural e historicamente um Outro de um sujeito humano que, por default, é masculino. A importância de Lévi-Strauss para essa formulação é reconhecida já nas páginas introdutórias de $O$ Segundo Sexo, e a dívida é retomada na resenha das Estruturas 
Mas Simone de Beauvoir não se limitou a aplicar uma noção de alteridade disponível e para a qual, de resto, havia outras fontes na tradição fenomenológica: ela deu a essa noção uma inflexão original. De fato, LéviStrauss, ao tratar das "estruturas elementares de parentesco" como constituintes e constituídas por relações de alteridade, indicou - sem tomar esse fato como problema teórico - que essas estruturas de alteridade envolvem relações entre homens e entre grupos de homens, que são de natureza simétrica, já que todo sujeito se opõe a um outro e é também um outro para ele. Já no caso das relações entre homens e mulheres não há simetria: "não é entre os homens e as mulheres que aparecem as relações de reciprocidade e de troca; elas se estabelecem por meio das mulheres, entre os homens; existe, e sempre existiu entre os sexos uma profunda assimetria..." (p. 945). Aqui, Simone de Beauvoir, aceitando a caracterização de Lévi-Strauss, deu contudo um passo adiante ao chamar a atenção para a existência de dois modos de oposição: uma oposição simétrica, tematizada nas 'estruturas elementares de parentesco', e uma oposição assimétrica, pressuposta por essas estruturas, mas silenciada enquanto tal. Simone de Beauvoir descreveu a oposição assimétrica assim: na dualidade de sexos, o termo masculino é ao mesmo tempo um termo positivo e o termo neutro, enquanto o termo feminino é apenas negativo. Isso mostra como Simone de Beauvoir estava pensando por conta própria ao longo das linhas que foram desenvolvidas por Louis Dumont, com a noção de oposição englobante, e por Roman Jakobson, com a noção de uma oposição entre um termo marcado e um termo não-marcado. A mulher é o termo marcado do par feminino-masculino, assim como a natureza é o termo marcado no par natureza-cultura.

Há outra contribuição importante nessa resenha de Simone de Beauvoir. Depois de afirmar que "o primeiro mérito do estudo de Lévi-Strauss é precisamente" mostrar que os "fatos humanos" como esse, em vez de resultarem de "deliberações refletidas", são "estruturas cujo todo precede as partes e cujo princípio regulador possui um valor racional, mesmo quando não é racionalmente concebido" (p. 949), ela formula uma pergunta: "De onde provêm a estrutura e o princípio?" Em vez de criticar Lévi-Strauss pela ausência de uma resposta - sendo que é preciso ter em mente que o que está em questão aqui é a oposição assimétrica descrita acima, e que não poderia ser atribuída a propriedades gerais do espírito humano -, ela dá duas pistas, uma delas em direção ao marxismo, e outra em direção ao existencialismo.

No primeiro caso, a pista são as primeiras palavras de uma citação incompleta e sem indicação de fonte (o leitor culto e de esquerda de Les Temps Modernes estava com a leitura em dia); talvez seja útil lembrar que a citação vem dos Manuscritos Econômico-Filosóficos. O contexto começa com Marx dizendo que, "na relação com a mulher, enquanto presa e enquanto criada para desfrute comum, expressa-se a infinita degradação na qual o ser humano existe para si mesmo, pois o segredo dessa relação tem sua expressão inambígua, definida, aberta e desvelada na relação do homem para com a mulher e na maneira pela qual a relação imediata e natural da espécie (humana) é apreendida". A conclusão de Marx é que a relação do homem para com o homem só escapará ao domínio de uma relação marcada pela natureza - isto é, uma relação marcada pelo 'regime de escassez', e a fortiori pela mulher como parte do regime de rareté -, tornando-se especificamente humana, quando a relação do homem para com a mulher for ela própria uma relação entre seres humanos plenos ("Do caráter dessa relação resulta até que ponto o ser humano se transformou em um ser da espécie, um ser humano, e se apreendeu como tal...", diz Marx). 
A segunda sugestão de Simone de Beauvoir é estender a ciência do humano de Lévi-Strauss com o existencialismo, que aqui tem o papel de indicar que há um espaço para a liberdade humana face a estruturas dadas. Assim, se a estrutura de troca por meio de mulheres é o meio pelo qual "se exprime e se realiza a transcendência do homem", essa "recusa da imanência, a exigência de uma superação" poderia aplicar-se no futuro também às próprias mulheres. Se nesta resenha Simone de Beauvoir não enuncia explicitamente essa conclusão, a citação de Marx antecipa as páginas finais do segundo volume do Segundo Sexo: o horizonte no qual a mulher seria capaz de escapar à prisão da imanência seria também o horizonte de uma sociedade sem alienação e sem classes de modo geral - conclusão que a afastou durante duas décadas do feminismo militante.

Talvez a polêmica entre Lévi-Strauss e Sartre tenha bloqueado a via sugerida por Simone de Beauvoir para a percepção de que estrutura e histórica não se opõem, e que a análise das estruturas familiares e de parentesco enquanto disciplina 'analítica' não se opõe à crítica 'dialética' da economia política das relações de gênero. A partir desse fato, constitui um interessante problema da história intelectual o desinteresse dos antropólogos pela relação teórica entre a teoria de Lévi-Strauss e os temas suscitados por Simone de Beauvoir.

Mauro W. Barbosa de Almeida é doutor em Antropologia Social pela Universidade de Cambridge, professor da Universidade Estadual de Campinas e diretor do Centro de Estudos Rurais (CERES). 
194 